\title{
INFORMATION AND COMMUNICATION
} TECHNOLOGY CAPABILITIES AND BUSINESS PERFORMANCE: THE CASE OF DIFFERENGES IN THE CZECH FINANCIAL SECTOR AND LESSONS FROM ROBOTIC PROCESS AUTOMATION BETWEEN 2015 AND 2020

\begin{abstract}
Martin Zelenka, Marek Vokoun
Department of Informatics, Faculty of Economics, Technical University of Liberec, Liberec, Czechia Department of Economics and Management, Faculty of Social and Economic Studies, Jan Evangelista Purkyne University, Usti nad Labem, Czechia
\end{abstract}

\section{MarekVokoun \\ Department of Informatics, Faculty of Economics, Technical University of Liberec, Liberec, Czechia marek.vokoun@ujep.cz \\ Article info Paper category: Preliminary Scientific Paper Received:19.10.2020. Accepted: $15 \cdot 6.2021$. JEL classification: $\mathrm{M}_{15}, \mathrm{~L}_{25}, \mathrm{G}_{20}$ DOI: https://doi.org/10.32728/ric.2021.71/5}

Keywords: Information Processes; Return on Equity; Banking; Profit Maximization; ICT Workers 


\section{ABSTRACT}

This paper analyzes the rapid onset of Robotic process automation (RPA) technologies in the Czech financial sector between 2015-2020. The development and experience from the "hype-and-fear" phase contributed to business process integration and technological spillovers are expected in the future. If ICT capabilities are the source of performance differences, then most likely candidates are inventory and finances business process integration and implemented Enterprise Resource Planning and Customer Relationship Management systems. The RPA should not be seen only as simple automation but as a complex instrument offering a lot of advantages with a focus on benefits for internal and external stakeholders.

PURPOSE. The goal is to qualitatively analyze the experience with RPA implementation and quantitatively assess ICT capabilities via analysis of differences between various organizational ICT activities and types of companies in the Czech financial sector.

DESIGN/METHODOLOGY/APPROACH. The qualitative case study was performed in the bank $\breve{C} S O B$, a.s. in 2019, respondents, owners of processes in the final part of automation, were chosen randomly from different departments of the bank. Data for the quantitative part comes from the ICT survey (Czech Statistical Office), business performance dataset (EMIS) and a case study about ICT capability implementation. Differences are assessed and indirectly interpreted using goodness-of-fit approach.

FINDINGS AND IMPLICATIONS. The results from the RPA case study revealed that the Czech financial sector is past the "hype and fear" phase and many companies focused on their return on investment and are beginning to focus more on other stakeholders. According to this development, the requirements and outputs are suggested in the phases of RPA implementation. The possible source of profitability performance differences are integrated business processes.

LIMITATIONS. Financial sector data are anonymized in ICT surveys and the measurement of the competitive advantage of ICT capabilities is only indirect. Qualitative approach is suggested with focus on technological efficiency measurement using data envelopment approach.

ORIGINALITY. This paper provides an understanding of the strong experience in RPA in Czech financial sector. Certain initial setbacks in RPA are expected and this paper suggest to focus on knowledge management (lessons learned) and other requirements influencing the successful RPA prototyping and implementation process. 


\section{INTRODUCTION}

The Information and Communication Technology (ICT) capabilities of enterprises are key resources for a business's success. Activities like the Business Process Integration (BPI) and Robotic Process Automatization (RPA) allow us to connect systems, people and information efficiently and in terms of overall business strategy.

The linkages between enterprise capabilities and business performance are not as straightforward as one would expect. The most empirically and theoretically studied capabilities are marketing capabilities. Kamboj and Rahman (2015) reveal a positive relationship between "doing great" in the marketing capability dimension and business performance. However, the relationship between some of the marketing capabilities and business performance appears to be negative or interdependent on factors from the strategic behavior of enterprises. In the study by Kaleka and Morgen (2019) feedback loop effects are suggested. Some promotional marketing capabilities (new subscriptions, free to try licenses, trial versions, etc.) are expected to have a negative effect on profits in the current accounting period and a positive effect in the future (Vokoun and Píchová, 2020).

There are many marketing capabilities which are based on the "old marketing mix" processes (product, price, place, and promotion) and combined with new technologies and scientific knowledge. Today's marketing mix requires Industry 4. 0 technologies like the Industrial Internet of Things (IIoT) and ICT knowledgeintensive services like automatization and Artificial Intelligence (AI). That is why we focus on the ICT aspect of business processes, namely the information processes in the enterprise information system (EIS, list of processes by Annisa, Sensuse and Noprisson, 2017). Those processes require ICT skilled labor and management with the ability to process data and information especially about customers or clients, hardware and software proficiency in general, as well as other business environment aspects (intellectual property rights, globalization tendencies, cybersecurity, compliance, etc.).

The goal of this paper is to analyze the differences in ICT capabilities according to the size of the enterprise and sector of the financial industry. We selected four types of financial services according to the NACE classification: life and non-life insurance, monetary intermediation, auxiliary financial and insurance services, and other financial services. The theoretical foundations are based on the ResourceBased View theory of information systems (Gupta et al., 2018) and dynamics (evolutionary nature) of complex systems (Malerba and McKelvey, 2020). ICT capabilities can directly and dynamically influence business performance and this paper explores this relationship. The selected factors of ICT capabilities are state of BPI, systems implementation and software development.

The Czech financial sector is a very competitive and innovative industry in comparison to other European countries (Hes and Jilkova, 2016). Clients (from the pri- 
vate and public sectors) enjoy innovation when it comes to financial services. This rapid development in Financial Technologies (FinTech) places high demands on process innovation and cost reductions. The market of financial services is changing due to the so-called "FinTech revolution" (banks granting access for the 3rd parties to their system). So, there is great potential for Application Programming Interfaces (APIs), Robotic Process Automation (RPA), Artificial Intelligence, the Internet of Things and Distributed Ledger Technology (DLT).

In the case of RPA, banks are mostly aiming to lower costs when it comes to routine manual work and to deliver tangible added value to the client (Mager, 2019). The term robotic process automation most commonly refers to configuring the software to do the work previously done by people (Lacity and Willcocks, 2016). There are predictions that RPA smart solutions can completely replace human workers (Carr, 2015). If the software cannot completely replace them, then at least free them from routine jobs (Ford, 2017). Public sector regulations can handle the impact of the new technologies but these regulations are slow and have a rather ambivalent impact (Mendling et al., 2018).

The RPA applications are usually adopted along with machine learning (ML) innovations. However, it is not widespread and the RPA applications still need to become "smarter" while we also need processes that can discover incorrect decisions which can otherwise remain unnoticed (van der Aalst, Bichler, Heinzl and 2018). The RPA skill belongs to a special set of skills and competencies for the digital transformation of enterprises. It is used in combination with cloud computing, agile program management, cybersecurity and business process management (Andriole, 2018).

Because data does not allow for the direct assessment of the capability performance relationship, this paper also summarizes the most important knowledge from current academic research and analyzes (semi-structured interviews) the RPA potential (as performance influencing ICT capability) in the Czech financial sector. This is done by a case study of critical factors for RPA implementation. This paper not only takes a look at the processes of financial institutions but also if RPA can be used in all enterprises in application areas like financial management and accounting, IT infrastructure maintenance and front-office processing. The automation of pharmaceutical safety is currently using artificial intelligence and RPA to automate the processing of adverse event reports (Schmider et al., 2019).

The robotic process automation and business process integration are rarely covered as a topic in the Web of Science or Scopus database. There were around 30 papers or proceedings currently in both databases at the end of 2019 when we prepared our first case study and there are about 3o new articles at the end of May 2021. The most cited paper is about annual returns on investment (ROI) of the RPA of routine back-office processes at Telefonica $\mathrm{O}_{2}$ (Lacity and Willcocks, 2016). The paper gives a great background for those looking to do RPA research. 
The ROI was around $200 \%$ and five "RPA Action Principles" were suggested also by companies operating in different industries. Firstly, a controlled experiment is suggested to test RPA capabilities. There are certain criteria for determining which processes can be automated. For example, processes which are: high-volume, standardized or strongly rule-based and mature processes. The next suggestion is to bring IT on board early because of IT security and change management policies. People will start fearing that RPA technology is going to take their job. Therefore, it is necessary to communicate the intended effect on jobs early in the RPA project. The last suggestion is to look for more sourcing options, like insourcing (buying licenses) with or without consulting services; and outsourcing via RPA, cloud RPA or other Business Process Outsourcing (BPO) providers (Lacity and Willcocks, 2016).

Three lessons for internal RPA adoption are suggested by Hallikainen, Bekkhus and Pan (2018). Again, the role of the IT department is crucial. It needs to be involved in the development, testing and production phases of the RPA project. Concerns of key employees about losing jobs have to be addressed by managers while employees have to feel comfortable when adapting to the change. The last suggestion is to select processes that are rules-based and require significant amounts of time and resources and the improvements have to be measured and evaluated. External RPA adoption is more suitable for organizations with hybrid structures. The high level of long-term trust between BPO and the enterprise is key for providing value-added to clients.

The RPA is a topic of many conferences and this last part of the literature review aims at the most interesting findings. What can be automated and how? Anagnoste (2018) provides a list of many specific processes and sub-processes in the finance sector and supply-chain management. According to the results, chat-bots and intelligent optical character recognition will be the source of the RPA boom in other industries.

The OCR smart technology can be used in RPA with 90\% efficiency in semiconductor manufacturing (Lin et al., 2018). RPA development can use the basic principles of workflow recording. Screen recording and Test-driven development are used in an agile and efficient way (Cewe, Koch and Mertens, 2018). The adoption of RPA is not easy because it is not smart enough and cannot be implemented in every organization. Principles of adoption and the expert process of identifying the most suitable for RPA is proposed by Bourgouin, Leshob and Renard (2018). The first step is to validate the process eligibility for RPA, then there is an evaluation of the RPA potential of the process. The third step is the evaluation of the RPA relevance when it comes to the process and the last step is the classification of the process for RPA.

There are leading RPA platforms like UiPath Studio, Automation Anywhere and Blue Prism. The first one seems to be the most valuable automation tool on the market (Issac, Muni and Desai, 2018). The manufacturing of defective products is a problem that can be solved by RPA implantation even in metal products manufacturing (Fominykh et al., 2018). The future of RPA and RPA platforms is introduced by 
(Anagnoste, 2017: 686): "The next 'big thing' in RPA is the integration of Artificial Intelligence solutions so that robots will understand when issues arise and will take decision(s) in order to solve it.".

Recent coronavirus pandemics only increased the high demand for automatization and digital transformations in the Czech financial sector. There are promising knowledge spillovers ( $\mathrm{Ng}$ et al., 2021) between RPA experienced sectors and sectors with a high potential like building and construction, smart product-service systems, portfolio management, aviation and supply chain. Pandemics also increased the high demand for the social assistance practices which can be redefined using RPA as human-technology hybrid actor social services (Ranerup and Henriksen, 2020).

\section{MATERIALS AND METHODS}

We used standard statistical hypotheses testing using $\chi_{2}$ tests (goodness-of-fit) to assess possible sources of competitive advantage. The hypotheses are aimed at the differences between 4 , branches of financial enterprises (Table 1.) and variables that relate to business process integration, as well as other ICT activities (Table 2.). Additionally, we also tested hypotheses about the differences between the size of the enterprise (Table 3.) and other variables of interests (Table 2.). In case of hypotheses testing (Table 6. and Table 7 .), we only allowed for $5 \%$ statistical significance level (denoted as alpha $5 \% * *$ and alpha $1 \% * * *$ ).

Table 1.: The frequency of the types of economic activities, based on the Czech Statistical Office data (2015)

\begin{tabular}{|c|c|c|c|c|c|}
\hline Abbr. & Type & NACE & Freq. & Percent & Cum. \\
\hline AUX & Auxiliary activities & $661-663$ & 120 & 46.88 & 46.88 \\
\hline MON & $\begin{array}{r}\text { Monetary } \\
\text { intermediation }\end{array}$ & 641 & 42 & 16.41 & 63.28 \\
\hline ОТН & $\begin{array}{r}\text { Other financial } \\
\text { service activities, } \\
\text { except insurance } \\
\text { and pension } \\
\text { funding }\end{array}$ & 649 & $5^{6}$ & 21.88 & 85.16 \\
\hline INS & $\begin{array}{l}\text { Insurance and } \\
\text { reinsurance }\end{array}$ & $65^{1-6} 5^{2}$ & 38 & 14.84 & 100 \\
\hline
\end{tabular}

Source: authors.

Data about ICT activities in 2014, comes from the Czech Statistical Office (CZSO) official survey. The latest 2015 ICT dataset for scientific use does not contain all business process variables and newer datasets have not been published yet. The questionnaire contains all kinds of questions regarding the use of ICT (Czech Statistical Office, 2015); however, the financial performance indicators are not included. Only some of the economic activities (industrial sectors) from the financial sector are 
analyzed (Table 1.). Almost half $(4,6.9 \%)$ of the sample is represented by financial enterprises that are characterized by activities auxiliary to financial services and insurance activities (AUX). Banks, savings banks and credit unions are represented by $16.4 \%$ and labeled as monetary intermediation (MON). There are $21.9 \%$ leasing, factoring and consumer credit enterprises that are labeled as other financial services (OTH). The last group is represented by $14.8 \%$ and consists of life and non-life insurance and reinsurance enterprises (INS).

The statistical summary of variables used in the results section are provided in Table 2. The variation coefficients of all variables are quite high. There are differences between companies based on their size (Table 3.) and industry type (Table 1.). On average, almost half of all enterprises have CRM and ERP systems. CRM data about clients are available to other information systems in $45 \%$ of the enterprises in the sample. About $21 \%$ of enterprises develop their SW in-house. The most integrated business processes are in finances $(54 \%)$ and operations $(31 \%)$.

Table 2.: Statistical summary of enterprises' characteristics and variables of interest, based on the Czech Statistical Office data (2015)

\begin{tabular}{|l|r|r|r|r|}
\hline \multicolumn{1}{|c|}{ Characteristics of enterprises } & N & \multicolumn{1}{c|}{ Mean } & \multicolumn{1}{c|}{ SD } & \multicolumn{1}{c|}{ Max } \\
\hline IT workers (internal and external) & 256 & 13.7 & 52.02 & 549 \\
Programmers (internal and external) & 256 & 4.13 & 16.75 & 205 \\
In-house SW developers/programmers & & & & \\
(\% of time - development) & 256 & 26.92 & 37.86 & 100 \\
Number of in-house SW developers & & & & \\
(non-programmers) & 256 & 4.81 & 30.76 & 344 \\
In-house SW developers/non- & & & & \\
programmers & & & & 100 \\
(\% of time - development) & 256 & 12.66 & 26.7 & 1 \\
SW in-house development & 256 & 0.21 & 0.41 & 1 \\
SW external development & & & & 1 \\
(outsourcing/cooperation) & 256 & 0.65 & 0.48 & 1 \\
ERP system implemented & 256 & 0.46 & 0.5 & 1 \\
CRM system implemented & 256 & 0.49 & 0.5 & 1 \\
CRM data available to other IS & 256 & 0.45 & 0.5 & 1 \\
Business process integration - & 256 & 0.2 & 0.4 & 1 \\
inventory & 256 & 0.54 & 0.5 & 0.4 \\
Business process integration - finances & 256 & 0.31 & 0.46 & 1 \\
Business process integration - & 256 & 0.24 & 0.43 & \\
operations, services & & & & \\
Business process integration - logistics & & & & 1 \\
\hline
\end{tabular}

Source: authors. 
The last variable is used for additional testing between the sizes of enterprises. In the data sample, there are only 2 micro-enterprises with 1 or fewer employees. The company sizes are well represented given the fact the analysis is in the 4 branches of the financial sector (Table 1.) where there are medium-sized to large companies (Table 3.). Unfortunately, the ICT survey does not contain business performance variables.

Table 3.: Statistical summary of enterprises' characteristics and variables of interest, based on the Czech Statistical Office data (2015)

\begin{tabular}{|c|c|c|c|}
\hline $\begin{array}{l}\text { Number of } \\
\text { Employees }\end{array}$ & Freq. & Percent & Cum. \\
\hline o to 9 & $5^{2}$ & 20.31 & 20.31 \\
\hline 10 to 29 & 74 & 28.91 & 49.22 \\
\hline 3o to 99 & 69 & 26.95 & $7^{6.17}$ \\
\hline 100 plus & 61 & 23.83 & 100 \\
\hline
\end{tabular}

Source: authors.

Business performance is measured indirectly in a data sample covering the financial sector in 2015. The dataset comes from the EMIS (2020) database. The sample covers 218 enterprises from the 4 groups (AUX, MON, OTH, INS). It is a comparable sample to the ICT survey because the same enterprises are participating in the CZSO ICT survey and represents the Czech financial market in those four categories well.

Table 4.: Statistical summary of 2015 financial performance, based on the EMIS data (2020)

\begin{tabular}{|c|c|c|c|c|c|}
\hline $\begin{array}{l}\text { Number of } \\
\text { Employees }\end{array}$ & Freq. & Mean & Std. Dev. & Min & $\operatorname{Max}$ \\
\hline $\begin{array}{l}\text { Profit before } \\
\text { income tax }\end{array}$ & 218 & 429.40 & 2052.23 & -218.19 & 17940.00 \\
\hline $\begin{array}{l}\text { Return on } \\
\text { Equity (ROE) } \\
(\%)\end{array}$ & 217 & 22.29 & 81.44 & -636.36 & $725 \cdot 7^{2}$ \\
\hline
\end{tabular}

Source: authors.

The RPA case study research was performed in the bank ČSOB, a.s. In 2019, more than 30 processes were automated. To prevent selection bias, respondents were chosen randomly from different departments of the bank. The research was performed on the owners of fully automated processes or owners of processes in the final part of automation (babysitting). The research question was aimed at their experience with RPAimplementation.

This research covers 13 processes from different units of the bank (Retail backoffice, Corporate back-office, HR, Compliance and Credits). The size measured in 
full-time employees (FTE) and maturity level is described in Table 5 . The maturity of the process is measured by the Capability Maturity Model (McKay, 2019).

Table 5.: The number of processes in the study.

\begin{tabular}{|l|r|r|r|r|}
\hline \multicolumn{1}{|c|}{ Maturity/Size } & $<0,5$ FTE & 0,5 -2, FTE & $<2$ FTE & Total \\
\hline Level 1 - Initial & 0 & 0 & 0 & 0 \\
Level 2 - & 1 & 0 & 1 & 2 \\
Repeatable & 1 & 2 & 1 & 4 \\
Level 3 - Defined & 1 & 3 & 1 & 5 \\
Level 4- & & & & \\
Managed & 0 & 1 & 1 & 2 \\
Level 5- & 3 & 6 & 4 & 13 \\
Optimizing & & & & \\
Total & & & & \\
\hline
\end{tabular}

Source: authors.

\section{RESULTS}

First, we present differences in ICT activities and compare them with the differences in business performance. In the first case, there are differences between the four branches (auxiliary activities, monetary intermediation, other financial service activities, except insurance and pension funding and Insurance and reinsurance) and ICT capabilities. Auxiliary activities were mostly the cause of differences in the case of business process integration of inventory activities and the case of the ERP system. The ratio of in-house and external SW development, BPI of operations and logistics were the same in all four branches (Table 6.) and were not a distinctive ICT capability in the financial sector.

Table 6.: The relationship between economic activity ( 4 branches) and ICT capabilities

\begin{tabular}{|l|r|r|}
\hline \multicolumn{1}{|c|}{ Business process integration, 4 branches } & Pearson $\boldsymbol{\chi}_{\mathbf{2}}$ & p-value \\
\hline Business process integration - inventory & 10.5 & $0.015^{* *}$ \\
Business process integration - finances & 9.2 & $0.026^{* *}$ \\
Business process integration - operations, services & 2.3 & $0.5^{12}$ \\
Business process integration - logistics & 4.3 & 0.230 \\
ERP system implemented & 16.0 & $0.001^{* * *}$ \\
CRM system implemented & 12.9 & $0.005^{* * *}$ \\
CRM data available to other IS & 14.3 & $0.003^{* * *}$ \\
SW in-house development & 1.3 & 0.725 \\
SW external development (outsourcing/cooperation) & 0.5 & 0.917 \\
\hline
\end{tabular}

Source: authors. 
The size was a factor of variability in the case of business process integration (inventory and finances), ERP system integration and the ratio of in-house SW development. The direct relationship between size class (ordinal category) was observed in the case of inventory BPI (from $5 \%$ to $20 \%$ ) and in-house SW development (from 11 to $31 \%$ ). In other cases, there were no differences (Table 7. .).

Table 7.: The relationship between the number of employees (size category) and ICT capabilities

\begin{tabular}{|l|r|r|}
\hline \multicolumn{1}{|c|}{ Business process integration - inventory } & Pearson $\boldsymbol{\chi}_{\mathbf{2}}$ & \multicolumn{1}{c|}{ p-value $^{*}$} \\
\hline Business process integration - inventory & 19.6 & $0.000^{* * *}$ \\
Business process integration - finances & 9.4 & $0.024^{* *}$ \\
Business process integration - operations, services & 3.9 & 0.274 \\
Business process integration - logistics & 1.0 & 0.795 \\
ERP system implemented & 15.2 & $0.002^{* * *}$ \\
GRM system implemented & 2.4 & 0.498 \\
CRM data available to other IS & 1.8 & 0.606 \\
SW in-house development & 6.9 & 0.076 \\
SW external development & & 0.4 \\
(outsourcing/cooperation) & 0.941 \\
\hline
\end{tabular}

Source: authors.

Business performance was measured using three variables. The financial sector is specific because there are no traditional sales like in manufacturing or other services. The revenues from loans and fees are a poor measure of business performance. In the banking sector, a more relevant indicator is the ability to avoid costs, generate profit and boost equity (Tier 1 capital). That is why these two indicators are preferred.

Table 8.: The relationship between the number of employees (size category) and ICT capabilities

\begin{tabular}{|l|r|r|r|r|r|r|r|}
\hline Variable & Branch & \multicolumn{1}{|c|}{ Obs. } & \multicolumn{1}{c|}{ Mean } & \multicolumn{1}{c|}{$\begin{array}{c}\text { Std. } \\
\text { Dev. }\end{array}$} & $\begin{array}{c}\text { Coeff. of } \\
\text { Var. }\end{array}$ & Min & \multicolumn{1}{c|}{ Max } \\
\hline ROE (\%) & MON & 39 & 16.3 & 29.0 & $178 \%$ & -16.6 & 100.0 \\
ROE (\%) & OTH & 63 & 10.3 & 105.7 & $1026 \%$ & -636.4 & 4.85 .3 \\
ROE (\%) & INS & 28 & 13.0 & 35.3 & $272 \%$ & -116.0 & 100.0 \\
ROE (\%) & AUX & 87 & 36.6 & 86.5 & $236 \%$ & -111.5 & 725.7 \\
EBT & MON & 39 & 2062.2 & 4541.7 & $220 \%$ & -218.2 & 1794.0 .0 \\
EBT & OTH & 63 & 118.5 & 199.6 & $168 \%$ & -78.5 & 808.3 \\
EBT & INS & 29 & 46.7 & 100.2 & $215 \%$ & -28.0 & 510.4 \\
EBT & AUX & 87 & 50.1 & 78.9 & $157^{2} \%$ & -26.3 & 384.6 \\
\hline
\end{tabular}

Source: authors. 
The variability of all indicators is substantial and variation coefficients (standard deviation to mean ratio) are too high to allow for the direct comparison of the means (Table 8.). The ranges of the means (mean plus one standard deviation) are substantially different. The highest and lowest profits are generated in the branch of monetary intermediation. The range of the mean in case of return on equity is the widest in the other and auxiliary activities. However, only in the case of other financial services, the coefficient of variation indicates a substantive high-risk premium (variation) in this industry.

Table 9.: The relationship between the number of employees (size category) and business performance

\begin{tabular}{|c|c|c|c|c|c|c|c|}
\hline Variable & $\begin{array}{l}\text { Size } \\
\text { Class }\end{array}$ & Obs. & Mean & $\begin{array}{l}\text { Std. } \\
\text { Dev. }\end{array}$ & Min & $\begin{array}{c}\text { Coeff. of } \\
\text { Var. }\end{array}$ & Max \\
\hline ROE (\%) & o to 9 & 41 & 24.0 & 176.0 & -636.4 & $733 \%$ & $725 \cdot 7$ \\
\hline ROE (\%) & 10 to 29 & 28 & $25 \cdot 7$ & 29.9 & -6.1 & $116 \%$ & 87.3 \\
\hline ROE (\%) & 3o to 99 & 66 & 24.7 & 36.6 & -67.8 & $148 \%$ & 180.9 \\
\hline ROE (\%) & 100 plus & $7^{6}$ & 15.8 & 28.5 & -116.0 & $180 \%$ & 100 \\
\hline EBT & oto 9 & 41 & 9.2 & 20.6 & -9.5 & $224 \%$ & 84.3 \\
\hline EBT & 10 to 29 & 28 & 25.0 & 42.9 & -26.3 & $172 \%$ & 180.2 \\
\hline EBT & 3o to 99 & 67 & 67.6 & 101.3 & -37.8 & $150 \%$ & $57^{8.8}$ \\
\hline EBT & 100 plus & $7^{6}$ & 1154.6 & 3369.8 & -218.2 & $292 \%$ & 17940.0 \\
\hline
\end{tabular}

Source: authors.

As in previous analysis, the variability of all indicators is substantial and variation coefficients are too high to allow for the direct comparison of the means (Table 9.). Microenterprises (9 and fewer employees) have the widest ranges of both indicators. It indicates a high-risk environment. Since the analysis is indirect, we can only assume a relationship between the ICT capabilities and those performance indicators. If ICT capabilities are the source of performance differences, then most likely candidates are inventory and finances business process integration and implemented ERP and CRM systems (see Table 6. and Table 7.). Data about financial institutions are mostly anonymized or unavailable and research in this field is complicated. The next case study about RPA sheds some light on the interdependence of people, data and other dimensions of the information system of the enterprise.

RPA Implementation: a qualitative case study

The interviews were done separately using a semi-structured questionnaire with open questions. Questions aimed to cover all phases of the RPA process (1. process selection/preparation, 2. automation implementation, 3. business-as-usual working). The results presented in this paper are based on six interviews with the owners of the processes and one control interview with a consultant providing services in the area of business architecture in ČSOB a.s. and other banks. This control interview can eliminate potential bias. 
The first key finding was that RPA as a method is not a source of main complications in RPA implementation. This conclusion is based on the fact that none of the interviews mentioned any trouble connected directly to the RPA itself. There was no mention of technical issues nor problems with the development of robotic algorithms and bugs causing a delay, etc.

A very important finding is that RPA is a lot about changing workers' mindset. Nearly all respondents mentioned that their workers had feared losing control over their processes. This slowed down the whole implementation. Also, employees responsible for granting access to company systems often denied access rights to robots. The same problem was with setting up new methodology or standards including software robots in the process. Their results regarding the responsible employees of RPA implementation suggest a combination of process skills, communication skills and programming skills which are not easy to find on the labor market.

The next finding is connected to the process of maturity. If the maturity of the process is low, then the RPA seems to bring more complications than savings. Process analysis and its optimization are necessary for RPA implementation and cannot be omitted. If so, there is probably a high risk of bugs during the implementation. The RPA is more complex and should not be seen only as a solution for every routine job, unless the process analysis was already done. The maturity of the process also influences the meeting of expectations in several FTE savings. Immature processes saved less FTE because more tasks had to stay in the hands of human workers.

From a more technical point of view, there is an issue of input data quality. Software robots need precise working interfaces which are not easy to achieve. The robot works better in the beginning and at the end of a process. The cooperation of the human worker and robot in the middle of a process may cause delays or mistakes. On the other hand, the output of robots seems to be without mistakes. This could lead to better data quality within the company in the future. Not only does data quality play a crucial role but also the quality of systems in which the robot operates. The efficiency of the robot is dependent on system reaction times. If it is implemented on slow systems (or on systems with a long system recovery time) it will not meet the full potential.

Issues connected to the RPA discovered in previous research were very similar to our findings. In our case study, we showed that proper process selection is based on maturity (Lacity, Willcocks, 2016), on rule-based criterion (Hallikainen, Bekkhus and Pan, 2018), employees mindset awareness, integration of business processes, sharing data and information and IT involvement in the RPA targeted process (Lacity and Willcocks, 2016).

The implementation of RPA can be divided into 4 phases (Figure 1.) in each different factor that has an impact on outputs from each phase. Factors can be seen also as requirements because its quality decides if the RPA project will be successful or not. The IT departments and ICT workers are essential when it comes to the smooth RPA development (Lacity and Willcocks 2016; Hallikainen, Bekkhus and Pan, 2018). 
Figure 1.: The factors influencing the RPA implementation process, our own elaboration based on Lacity, Willcocks (2016), Hallikainen, Bekkhus, Pan (2018)

\begin{tabular}{|c|c|c|}
\hline Requirements & Phase & Outputs \\
\hline $\begin{array}{l}\text { Early IT department onboarding } \\
\text { Criteria for process selection } \\
\text { Employee's awareness } \\
\text { Sourcing decision } \\
\text { RPA project team selection } \\
\text { Risk management procedures }\end{array}$ & Preparation & $\begin{array}{r}\text { Business process candidates for RPA } \\
\text { A solution team } \\
\text { RPA Directives }\end{array}$ \\
\hline $\begin{array}{l}\text { IT involvement } \\
\text { Deep analysis of processes (UMP } \\
\text { BPMN) } \\
\text { Communication rules } \\
\text { Interface preparation }\end{array}$ & Implen & $\begin{array}{r}\text { RPA prototype optimized } \\
\text { RPA processes ready to be used } \\
\text { Lesson learnt }\end{array}$ \\
\hline $\begin{array}{l}\text { IT support } \\
\text { Communication roles }\end{array}$ & Babysitting & $\begin{array}{r}\text { Solution optimized } \\
\text { Lesson learnt }\end{array}$ \\
\hline $\begin{array}{l}\text { IT support (response time) } \\
\text { Knowledge management } \\
\text { Business process reengineering }\end{array}$ & Production & $\begin{array}{r}\text { effectivity and data quality, } \\
\text { flexibility } \\
\text { Strategy changes }\end{array}$ \\
\hline
\end{tabular}

Source: Authors.

The Czech financial sector is in the second phase of RPA evolution (Figure 2.). It is important to notice the RPA projects have feedback using lessons learned and changes in the local or overall strategy which leads to a correction in the selection of a process suitable for RPA within the company. This back-loop can also affect the funding of RPA and treating risk. This growth is possible thanks to a recent FinTech development (Hes and Jilkova, 2016). 
Figure 2.: The development of the RPA in the Czech financial sector, our own estimation based on RPA evolution in Lacity and Willcocks (2018) and case study results

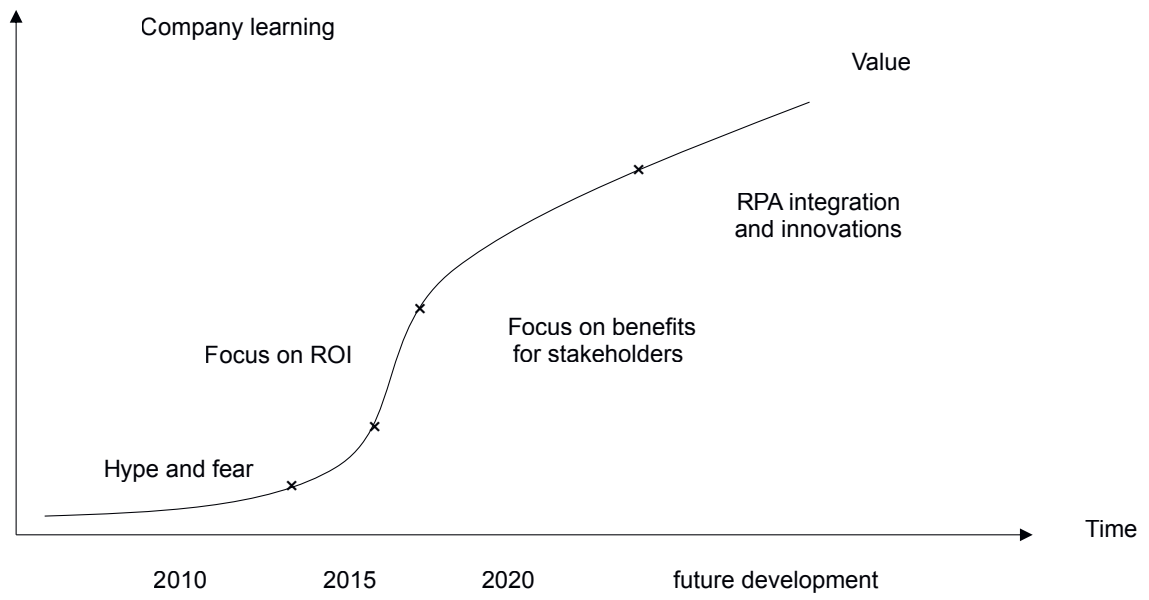

Source: Authors.

The value taken from this research is in the analysis of the interfaces between automated processes and processes done in the traditional way (including human workers). It is the first analysis of RPA in the Czech financial sector and it is based on a rather old data set (2014) and interview in one of the larger banks in the Czech financial sector. Further research should focus on critical factors of RPA implementation and the "organizational culture and human labor impacts". There is also the question of losing knowledge and skills by which human workers may suffer. From a technical point of view, the RPA is only a bridge to more sophisticated IT innovations. It is expected that AI together with RPA will influence the labor market by increasing productivity in other services as well. 


\section{CONCLUSION AND DISCUSSION}

There is a strong growth potential for the RPA in the banking sector (NACE 641). Given the development and experience from the "hype-and-fear" phase, technological spillovers are expected in private sector and thanks to the "bank citizen identity" authentications services in the public sector as well. It is given by the highest average number of programmers (ICT skilled workers) in comparison to other non-IT services.

The level of the business process integration is mostly high or highest in the area of inventory, finances, CRM, logistics and operations in the banking sector, insurance, other financial services, while the lowest level of BPI is in the field of auxiliary financial services. Integrated business processes in inventory, finances and implemented CRM and ERP systems are possible capabilities responsible for differences in business performance measured by profit and return on equity.

The quantitative part dealt with indirect indicators and showed differences between four industry branches and four size categories of enterprises in 2014, in the Czech Republic. There are differences in ICT processes and other characteristics. The share of in-house and extremal SW development is similar in all branches.

The qualitative case study showed remarkably similar results just as in previous papers (Lacity and Willcocks, 2016). The RPA should not be seen only as simple automation but as a complex instrument offering a lot of advantages if it operates in a precise working and stable company environment.

The RPA policy implications are summarized in Figure 2. and Figure 1. Our suggestions are based on the development in the Czech financial sector where a lot of resources were aimed at the development of ICT capabilities including RPA. The RPA projects between 2015-2020 are going to be sources of knowledge that are going to be utilized in further development of competitive advantage in financial services. This knowledge is to some extent transferable to other service sectors of the national economy which can make the "hype-and-fear" phase shorter and company learning faster.

This study has many limitations given the fact that financial sector data are anonymized in ICT surveys. The measurement of the competitive advantage of ICT capabilities is only indirect. The return on investment of RPA projects can be measured only indirectly because the outputs of these projects are intertwined with other company processes. Our suggestion for further research is to assess the technical cost efficiency in the financial sector between early adopters of RPA and followers.

There are many methodological and reediness-related RPA challenges (Syed et al., 2020). Given the strong experience in RPA in Czech financial sector and expected knowledge spillovers, we suggest focusing also on the innovations caused by RPA on management structures in private and public sector and the behavior of their employees and clients. 


\section{ACKNOWLEDGEMENT}

This paper is an output of the project CZ.02.1.01/0.0/0.0/17-04.8/0007435 SMART ITI of Jan Evangelista Purkyně University in Usti nad Labem, "Smart City

- Smart Region - Smart Community". And it is also supported by the TUL project SGS n. 21301 "Project Management and Information Systems in Quality and Supply Chain Management". 


\section{REFERENCES}

Aalst, Wil M. P. van der, Martin Bichler, and Armin Heinzl. "Robotic Process Automation." Business \& Information Systems Engineering 60, no. 44 (August 2018): 269-272. https://doi.org/10.1007/ s12599-018-0542-4.

Anagnoste, Sorin. "Robotic Automation Process - The next Major Revolution in Terms of Back Office Operations Improvement." Proceedings of the International Conference on Business Excellence 11, no. 1 (July 2017): 676-686. https://doi.org/10.1515/picbe-2017-0072.

Anagnoste, Sorin. "Robotic Automation Process - The Operating System for the Digital Enterprise." Proceedings of the International Conference on Business Excellence 12, no. ( May 2018): 54-69. https:// doi.org/10.2478/picbe-2018-0007.

Andriole, Stephen J. "Skills and Competencies for Digital Transformation." It Professional 20, no. 6 (December 2018): $7^{8-81 . ~ h t t p s: / / d o i . o r g / 10.1109 / M I T P .2018 .2876926 . ~}$

Annisa, Nadia Nur, Dana Indra Sensuse, and Handrie Noprisson. "A Systematic Literature Review of Enterprise Information Systems Implementation." In 2017 International Conference on Information Technology Systems and Innovation (ICITSI), 291-296, 2017. https://doi.org/10.1109/ ICITSI.2017.8267959.

Bourgouin, Audrey, Abderrahmane Leshob, and Laurent Renard. Towards a Process Analysis Approach to Adopt Robotic Process Automation. Los Alamitos: Ieee Computer Soc, 2018.

Cewe, Christoph, Daniel Koch, and Robert Mertens. "Minimal Effort Requirements Engineering for Robotic Process Automation with Test Driven Development and Screen Recording. "In Business Process Management Workshops, edited by Ernest Teniente and Matthias Weidlich, 642-64.8. Lecture Notes in Business Information Processing. Springer International Publishing, 2018.

Czech Statistical Office. "ICT Questionnaire.”Vzory výkazů, 2015. http://apl.czso.cz/pll/vykazy/ pdf 113 ?xvyk=2097\&cd=0.

EMIS. "Emerging markets research, data and news". Database, 2020. https://www.emis.com.

Fernandez, Dahlia, and Aini Aman. "Impacts of Robotic Process Automation on Global Accounting Services." Asian Journal of Accounting and Governance 9 (2018): 123-131. https://doi.org/10.17576/AJAG2018-09-11.

Fominykh, D. S., A. F. Rezchikov, V. A. Kushnikov, V. A. Ivashchenko, A. S. Bogomolov, L. Yu Filimonyuk, O. N. Dolinina, O. V. Kushnikov, T. E. Shulga, and V. A. Tverdokhlebov. "Problem of Quality Assurance during Metal Constructions Welding via Robotic Technological Complexes." In International Conference Information Technologies in Business and Industry 2018, Pts 1-4, 1015:UNSP o32169. Bristol: Iop Publishing Ltd, 2018.

Gupta, Gaurav, Kevin Tee Liang Tan, Yaw Seng Ee, and Cynthia Su Chen Phang. "Resource-Based View of Information Systems: Sustainable and Transient Competitive Advantage Perspectives." Australasian Journal of Information Systems 22 (January 22, 2018). https://doi.org/10.3127/ajis.v22io.1657.

Hallikainen, P., R. Bekkhus, and S.L. Pan. "How OpusCapita Used Internal RPA Capabilities to Offer Services to Clients." MIS Quarterly Executive 17, no. 1 (2018): 41-52

Hes, Ales, and Petra Jilkova. "Position of Low-Cost Banks on the Financial Market in the Czech Republic," 2016. https://www.um.edu.mt/library/oar/handle/123456789/29576.

Issac, Ruchi, Riya Muni, and Kenali Desai. Delineated Analysis of Robotic Process Automation Tools. New York: Ieee, 2018. 
Lacity, M.C., and L.P. Willcocks. "Robotic Process Automation at Telefónica O2." MIS Quarterly Executive 15, no. 1 (2016): 21-35

Lin, Ssu Chieh, Lian Hua Shih, Damon Yang, James Lin, and Ji Fu Kung. Apply RPA (Robotic Process Automation) in Semiconductor Smart Manufacturing. New York: Ieee, 2018.

Mager, C. "Innovation in Transaction Banking: What Can Emerging Technologies Deliver?" Journal of Payments Strategy and Systems 13, no. 1 (2019): 66-71

Malerba, Franco, and Maureen McKelvey. "Knowledge-Intensive Innovative Entrepreneurship Integrating Schumpeter, Evolutionary Economics, and Innovation Systems." Small Business Economics 54, no. 2 (February 1, 2020): 503-522. https://doi.org/10.1007/s11187-018-0060-2.

Mendling, J., G. Decker, H.A. Reijers, R. Hull, and I. Weber. "How Do Machine Learning, Robotic Process Automation, and Blockchains Affect the Human Factor in Business Process Management?" Communications of the Association for Information Systems 43, no. 1 (2018): 297-320 https://doi. org/10.17705/1CAIS. 04319 .

Ng, Kam K. H., Chun-Hsien Chen, C. K. M. Lee, Jianxin (Roger) Jiao, and Zhi-Xin Yang. "A Systematic Literature Review on Intelligent Automation: Aligning Concepts from Theory, Practice, and Future Perspectives." Advanced Engineering Informatics 47 (January 1, 2021): 101246. https://doi.org/10.1016/j. aei.2021.101246.

Piccoli, G., and F. Pigni. "TRIPBAM: Leveraging Digital Data Streams to Unleash Savings." Communications of the Association for Information Systems 39, no. 1 (2016): 556-574

Ranerup, Agneta, and Helle Zinner Henriksen. "Digital Discretion: Unpacking Human and Technological Agency in Automated Decision Making in Sweden's Social Services." Social Science Computer Review, 2020. https://doi.org/10.1177/0894439320980434.

Schmider, Juergen, Krishan Kumar, Chantal LaForest, Brian Swankoski, Karen Naim, and Patrick M. Caubel. "Innovation in Pharmacovigilance: Use of Artificial Intelligence in Adverse Event Case Processing." Clinical Pharmacology \& Therapeutics 105, no. 4 (April 2019): 954-961. https://doi.org/10.1002/ cpt.1255.

Syed, Rehan, Suriadi Suriadi, Michael Adams, Wasana Bandara, Sander J. J. Leemans, Chun Ouyang, Arthur H. M. ter Hofstede, Inge van de Weerd, Moe Thandar Wynn, and Hajo A. Reijers. "Robotic Process Automation: Contemporary Themes and Challenges." Computers in Industry 115 (February 2020): 103162. https://doi.org/10.1016/j.compind.2019.103162.

Van Belkum, S., N. Brun, S. Cleve, P. McGovern, M. Lumpkin, P.-E. Schaeffer, T. Pauli, J. Trethowan, and T. Netzer. "Artificial Intelligence in Clinical Development and Regulatory Affairs - Preparing for the Future." Regulatory Rapporteur 15, no. 10 (2018): 17-21

Vokoun, Marek, and Romana Pichova. "Market Orientation and Marketing Innovation Activities in the Czech Manufacturing Sector." International Journal of Financial Studies 8, no. 1 (March 2020): 10. https://doi.org/10.339o/ijfs8o10o10. 